\title{
Protective immunity against Trypanosoma cruzi
}

\author{
Cecilia Parodi, Angel Marcelo Padilla, Miguel Angel Basombrío/ ${ }^{+}$ \\ Instituto de Patología Experimental, Consejo Nacional de Investigaciones Científicas y Técnicas, Universidad Nacional de Salta, Argentina
}

Upon infection, Trypanosoma cruzi triggers a strong immune response that has both protective and pathological consequences. In this work, several important questions regarding protective immunity are reviewed. Emphasis is placed on recent studies of the important protective role of $C D 8^{+} T$ cells and on previous studies of immunisation of domestic $\mathrm{T}$. cruzi reservoirs that sought to address practical vaccination problems. Research on the maturation of memory cells and studies indicating that the prevalence of T. cruzi-specific T-cell responses and a high frequency of committed $C D 8^{+} T$ cells are associated with better clinical outcomes are also reviewed. Additionally, animal models in which protection was achieved without immunopathological consequences are discussed.

Key words: Trypanosoma cruzi - immunity - CD8 ${ }^{+} \mathrm{T}$ cells

Clinical studies indicate that Trypanosoma cruzi infection results in a state of host resistance that controls parasite load after one to three months. Parasitemia levels are high during the first few weeks of infection but decrease thereafter to almost undetectable levels, as indicated by parasite detection using fresh blood mounts, hemocultures, xenodiagnosis or polymerase chain reaction (PCR). Evidence that an otherwise progressive and lethal infection is usually suppressed by the immune system is provided by cases of reactivation or appearance of atypical clinical presentations of acute $T$. cruzi infection in patients with acquired immunodeficiencies (Simao Ferreira 1999) or human immunodeficiency virus infections (Karp \& Arwaerter 2007).

Experimental mouse models, in which primary and secondary inoculations with $T$. cruzi may be planned at desired sequences and intervals, have been used to demonstrate that control of parasite load and survival during the chronic phase are the effects of a general protective mechanism elicited by primary infection. When chronically infected mice are again challenged with virulent T. cruzi, they do not exhibit a pathological response, whereas naive control mice experience high parasite load and high mortality (Basombrío 1981). For many years, inoculations with an attenuated $T$. cruzi culture (TCC) strain, containing mostly epimastigote forms, provided our laboratory with a method of reliably inducing protective immunity. This technique resulted in stronger immunity for a longer duration than either selected recombinant $T$. cruzi antigens plus adjuvants or killed parasites. Although this method is not approved for human vaccination trials, it has allowed us to study

Financial support: CONICET

+Corresponding author: basombri@unsa.edu.ar

Received 14 April 2009

Accepted 8 May 2009 practical questions pertaining to vaccination against $T$. cruzi in laboratory animals and domestic reservoirs.

Here, we review several important questions regarding protective immunity against $T$. cruzi. Although there is a vast literature on the subject, we place emphasis on experiences from our laboratory. Many of these research questions are longstanding but have been reformulated as technical progress provides new perspectives.

Have animal models of Chagas disease contributed evidence for or against the theory of autoimmune pathogenesis?

It is tempting to hypothesise that the immune response itself causes disease. From this perspective, one would expect to detect pathology when the immune system is actively suppressing T. cruzi load. A first series of experiments in our laboratory used the virulent Tulahuen strain of T. cruzi, later identified as T. cruzi IIe (TCIIe), to induce primary and secondary infections in mice (Table). Blood parasite load and mortality were clearly reduced after the second challenge, but the mice nevertheless developed severe heart and muscle lesions (Basombrío 1981). Studies using the T. cruzi I (TCI) lineage provided findings consistent with these results, showing that some TCI strains induced serious tissue lesions despite minimal or undetectable parasitemia (Cardozo 2003). However, in several experiments in which a highly attenuated primary infection by the TCC strain (TCI lineage) (Diosque et al., unpublished observations) preceded a virulent TCIIe challenge, many desirable vaccination effects were demonstrated without immunopathology (Basombrío et al. 1982). Taken together, these studies indicate that the relationship between parasite load, inflammation and pathology in $T$. cruzi infection is highly dependent on the lineage of the infecting parasite and that protective immunisation does not necessarily trigger an immunopathological response. Therefore, immunisation with TCC parasites confers protection against re-challenge and does not lead to immunopathology, which would be expected in an autoimmunity context. 
TABLE

Summary of studies on parasite load and histopathology after sequential inocula of Trypanosoma cruzi in Swiss mice

\begin{tabular}{lccc}
\hline $\begin{array}{l}\text { Priming } \\
\text { infection }\end{array}$ & $\begin{array}{c}\text { Challenge } \\
\text { infection }\end{array}$ & $\begin{array}{c}\text { Parasite } \\
\text { load }\end{array}$ & Histopathology \\
\hline- & Tul (IIe) & +++ & +++ \\
Tul (IIe) & Tul (IIe) & \pm & +++ \\
- & TCC (I) & - & - \\
TCC (I) & Tul (IIe) & \pm & \pm \\
- & Wild isolates & \pm & ++ \\
TCC (I) & Wild isolates & \pm & \pm \\
- & PalDal(I) & \pm & +++ \\
\hline
\end{tabular}

PalDa1(I): a T. cruzi isolate; TCC (I): T. cruzi culture I; Tul (IIe): Tulahuen IIe; ++: moderate; +++: severe; \pm : slight; -: not detectable.

\section{What is the role of $\mathrm{CD8}^{+} \mathrm{T}$ cells in Chagas disease?}

T. cruzi is an intracellular pathogen that replicates in the cytoplasm of a wide variety of mammalian host cells, including macrophages and cardiac myocytes. Robust $\mathrm{CD}^{+}$and $\mathrm{CD}^{+} \mathrm{T}$-cell responses are needed to protect against this protozoan, since mice lacking either of these T-cell subsets succumb to infection (Tarleton et al. 1992, 1996, Padilla et al. 2007). In particular, CD8 ${ }^{+}$ $\mathrm{T}$ cells are a critical component of protective immunity in both mouse models and human patients (Alvarez et al. 2008). The significant role of $\mathrm{CD}^{+} \mathrm{T}$ cells during $T$. cruzi infection is demonstrated by their predominance in non-lymphoid tissues not only in experimental models, but also in the myocardium of $T$. cruzi-infected cardiac patients (Vogt et al. 2008). $\mathrm{CD}^{+}$and $\mathrm{CD}^{+} \mathrm{T}$ cells also secrete interferon- $\gamma($ IFN- $\gamma)$, which is crucial for activating macrophages that exert trypanocidal activity via nitric oxide (Muñoz-Fernandez et al. 1992).

Although $\mathrm{CD}^{+} \mathrm{T}$ cells mount a substantial immune response against $T$. cruzi infection, the parasite may survive and establish a lifelong chronic infection in the host (Martin \& Tarleton 2006, Tzelepis et al. 2006). This parasitic persistence contributes to the development of symptoms many years or decades after initial infection in approximately one-third of chronically infected individuals (Tarleton 2001, 2003).

What are the contributions of experimental mouse models to the analysis of T-cell responses to persistent or resolved $T$. cruzi infections?

When T. cruzi infection occurs, the innate and acquired immune responses are characterised by the recruitment of dendritic cells, macrophages, natural killer (NK) cells, and B and T lymphocytes, as well as their secretion of soluble factors (cytokines and chemokines). Once parasite load is controlled in chronically infected mice, the majority of $T$. cruzi-specific $\mathrm{CD}^{+} \mathrm{T}$ cells display a $\mathrm{T}$ effector or $\mathrm{T}$ effector memory $\left(\mathrm{T}_{\mathrm{EM}}\right)$ phenotype $\left(\mathrm{CD} 62 \mathrm{~L}^{\mathrm{lo}}, \mathrm{CD} 122^{\mathrm{lo}}, \mathrm{CD} 127^{\mathrm{lo}}\right)$. This phenotype correlates with a late-differentiation pattern and its maintenance has been thought to be antigen-dependent (Martin \& Tarleton 2005). However, after pathogen clearance by drug treatment, long-term exposure to T. cruzi does not exhaust pathogen-specific $\mathrm{CD} 8^{+} \mathrm{T}$ cells, which maintain their potential to address re-infection (Bustamante et al. 2008). In this case, the development of a stable, antigenindependent $\mathrm{T}_{\mathrm{CM}}$ ( $\mathrm{T}$ central memory) cell population $\left(\mathrm{CD} 62^{\mathrm{hi}}, \mathrm{CD} 122^{\mathrm{hi}}, \mathrm{CD} 127^{\mathrm{hi}}, \mathrm{CCR} 7^{\mathrm{hi}}\right.$, and increased Bcl2 expression) has been noted. This population provides better protective immunity upon re-challenge than $\mathrm{T}$ effector or $\mathrm{T}_{\mathrm{EM}}$ cells in chronically infected mice. The possibility that phenotypic reversion occurs after parasitic load is decreased has important implications in human disease, as it may represent a new means of assessing treatment efficacy.

The influence of parasite persistence on the immune response to $T$. cruzi has also been studied in our laboratory. We hypothesised that if a memory mechanism operates in the absence of infection, long-term resistance to virulent reinoculation should persist regardless of whether the primary infection was cured. In support of this hypothesis, treatment of TCC-inoculated mice with benznidazole did not terminate resistance to virulent inocula administered as late as 330 days after primary infection (Basombrío et al. 2002b). However, TCC inoculation of drug-treated mice did diminish their longterm (1 year) ability to resist secondary challenge. These observations suggest that both parasite persistence and immunological memory contribute to long-term resistance to re-infection.

\section{Is there a relationship between disease progression and the pattern of T-cell differentiation in T. cruzi- infected humans?}

During persistent human viral infection, antigenprimed $\mathrm{CD} 8^{+} \mathrm{T}$ cells may be classified as having early, intermediate and late-differentiated phenotypes based on their sequential down-regulation of CCR7, CD28, and CD27 and up-regulation of cytotoxic factors (Appay et al. 2002, Appay \& Rowland-Jones 2004). Protective immunity is best conferred by early-differentiated $\mathrm{T}$ cells, which possess potent proliferative capacity (Appay \& Rowland-Jones 2004). Meanwhile, highly differentiated $T$ cells present signs of senescence during chronic infection, presumably due to exhaustion after persistent activation and restimulation (Barber et al. 2006, Hinrichs et al. 2006).

In chronically $T$. cruzi-infected patients presenting severe disease, the phenotypic profile of the antigenexperienced memory $\mathrm{CD} 8^{+} \mathrm{T}$-cell population is enriched in fully differentiated memory CD45RA ${ }^{\mathrm{lo}}, \mathrm{CD} 27^{\mathrm{lo}}$, $\mathrm{CD} 28^{\text {lo }} \mathrm{CD}^{+} \mathrm{T}$ cells (Laucella et al. 2004). Similarly, a low frequency of $T$. cruzi-specific CD $8^{+} \mathrm{T}$ cells has been observed in these patients, perhaps due to less efficient generation of memory $\mathrm{CD} 8^{+} \mathrm{T}$ cells or more marked decline in memory T-cell function over time. This apparent impairment of $\mathrm{CD} 8^{+} \mathrm{T}$-cell responses is associated with an increased frequency of fully differentiated memory $\mathrm{CD}^{+} \mathrm{T}$ cells and a high apoptosis rate, possibly reflecting $\mathrm{CD} 8^{+} \mathrm{T}$-cell exhaustion (Alvarez et al. 2008). Conversely, more frequent $T$. cruzi-specific $\mathrm{T}$-cell responses 
are associated with better clinical outcomes, suggesting that protection from infection is related to an increased prevalence of highly competent, early-differentiated $\mathrm{CD}^{+} \mathrm{T}$ cells, which has been observed in patients with mild or no disease symptoms (Albareda et al. 2006).

\section{Is protective immunity capable of completely pre- venting re-infection?}

Vaccine testing in mice is primarily composed of measurements of acute-stage parasitemia and mortality. Some studies have adopted more sensitive determinations of parasitemia, including hemoculture (Machado et al. 2006), xenodiagnosis (Basombrío et al. 1986, Basso et al. 2007), histopathological studies (Basombrío \& Besuschio 1982, Basombrío et al. 1986, Machado et al. 2006, Hoft et al. 2007) and electrocardiographic measurements (Cuneo et al. 1989). However, perhaps the most stringent method of demonstrating the absence of infection or "sterile immunity" after inoculation is serological testing. To explore this possibility, we applied the complement-mediated lysis (CML) test developed by Krettli and Brener (1982) to a mouse model of T. cruzi infection that included wild T. cruzi isolates as well as TCC and Tulahuen strains. While many animals appeared protected from re-infection based on several parasitemia detection tests, sub-patent infections were demonstrated by the presence of lytic antibodies. Nevertheless, a significant proportion of mice (8/18 for wild T. cruzi infection, 25/28 for Tulahuen infection) lacked lytic antibodies, suggesting a complete absence of re-infection in TCC strain-immunised mice (Gomez et al. 1996). The CML test demonstrated infection by the Tulahuen and wild isolates but not by the TCC strain, which, besides being attenuated, did not elicit lytic antibodies. However, recent experiments have demonstrated TCC parasite persistence by hemoculture and real-time PCR after immunosuppression of mice infected with TCC trypomastigotes from tissue cultures (Padilla et al., unpublished observations). These results suggest that protective immunisation against $T$. cruzi can prevent re-infection after secondary challenge, although this strong immunity may be induced by a subpatent, immunizing infection. Field trials in dogs included negative indirect hemagglutination (IHA) tests that indicated the absence of infection in immunised animals (Basombrío et al. 1993). Although the CML and IHA tests are based on distinct reactions, the latter has also been used to infer therapeutic success in clinical settings.

\section{Can the prevention of infection be gauged by pa- rameters indicative of disease?}

In "premunition" experiments in mice challenged with the Tulahuen strain TCIIe, re-infection lethality and blood parasite load were strongly suppressed. However, these mice suffered from severe muscle, intestine and heart histopathological lesions (Basombrío 1981). Using the same experimental design but replacing the Tulahuen strain with the attenuated TCC strain during primary infection, lethality and parasite load were again suppressed during secondary infection. Additionally, many measurable parameters of histopathological dam- age, including inflammatory mononuclear infiltration, necrosis and fibrosis, indicated protective immunity without immunopathological side effects (Basombrío et al. 1982, Basombrío \& Besuschio 1982).

In another experiment, the frequency of certain electrocardiographical alterations, such as persisting auriculoventricular blocks, supraventricular tachycardia and sinus bradycardia was measured in $T$. cruzi-infected mice previously or never primed with TCC strain inocula (Fig. 1). The TCC-primed group displayed a significant reduction in electrocardiographic alterations $(\mathrm{Cu}-$ neo et al. 1989). Pathology of heart and skeletal muscle, tissue parasite load and inflammation, mortality and parasitemia were also reduced in T. cruzi-infected mice previously immunised with DNA vaccines containing the trans-sialidase family genes ASP-1, ASP-2, or TSA-1 (Garg \& Tarleton 2002, Vasconcelos et al. 2004).

Do the time intervals between immunisation and infection in experimental models properly mimic those of natural $T$. cruzi infection in the field?

Unfortunately, although the duration of protective immunity development is an important parameter, it is tested and reported very infrequently for $T$. cruzi vaccines. The fact that protection by non-replicating $T$. cruzi antigens is relatively short-lived (1-3 months) unless booster injections are provided probably precluded the investigation of many candidate immunogens. In this regard, the vaccination experiments of Machado et al. (2006), which used recombinant adenoviruses expressing two T. cruzi antigens in a replicating organism, are very promising, particularly since protection against re-infection was demonstrable $31 / 2$ months after immunisation. Moreover, many of the immunised mice developed sterile immunity, as suggested by negative hemocultures, and all protected mice survived a $100 \%$ lethal challenge.

Tzelepis et al. (2006) studied the kinetics of the CD $8^{+}$ $\mathrm{T}$-cell cytotoxic response and IFN- $\gamma$ secretion after in-

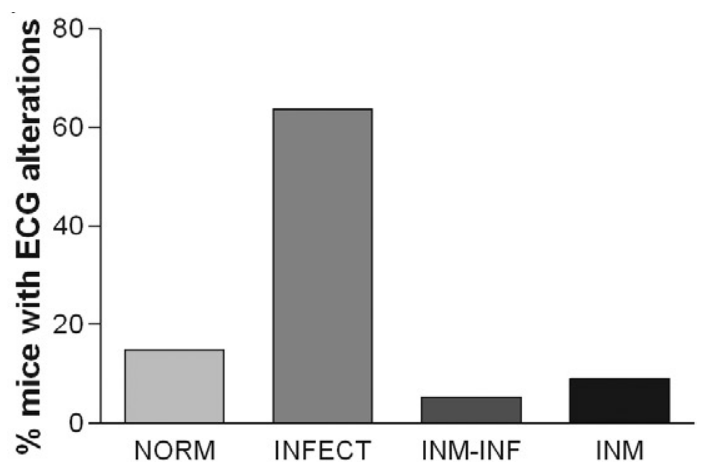

Fig. 1: prevention of electrocardiographic (ECG) alterations in mice by pre-inoculation of TCC epimastigotes. First degree AV blocks, sinus bradycardia and supraventricular tachycardia; INFECT: mice inoculated with virulent Trypanosoma cruzi; INM: only received T.cruzi culture (TCC) inoculations; INM-INF: same as INFECT, but pre-inoculated with attenuated TCC T. cruzi; NORM: non inoculated mice (data from Cuneo et al. 1989). 
fection of naive mice or mice vaccinated with trans-sialidase or ASP-2 antigens. Following peak parasitemia, these responses reached a maximum around days 1530 of infection, subsequently declining slowly but still detectable by day 240. In particular, cytotoxic activity against ASP-2 peptide-coated cells was remarkably high eight months after initial infection. While the cytotoxic response peaked after the highest parasitemia level in naive mice, vaccinated mice responded much more rapidly, leading to more successful protection. Inoculation with the TCC strain induces lifetime resistance to reinoculation with virulent wild $T$. cruzi isolate, as tested with inocula administered 312, 366 or 436 days after primary TCC infection (Basombrío \& Arredes 1987). Thus, the duration of the development of protective immunity prior to re-infection seems essential to vaccination in the field. The importance of this time interval between primary and secondary infection in the field may explain why killed $T$. cruzi vaccines that were highly protective in laboratory tests were only weakly protective in field tests on guinea pigs (Basombrío 1990).

Is resistance to the Tulahuen strain induced by attenuated TCC inoculation also applicable to a variety of wild $T$. cruzi isolates?

Vaccine development is often hampered by antigenic modulation and pathogenic diversity. These survival mechanisms, allowing pathogens to evade the protective effects of vaccines, are well characterised for influenza and papillomavirus and may also be utilised by Plasmodium sp., Giardia sp. and African trypanosomes. However, there is no evidence that vaccines protective against particular T. cruzi laboratory strains will fail when tested against wild parasites. In fact, it has been found that the attenuated TCC strain belonging to lineage I (TCI) may confer protection against a secondary challenge with the lineage II Tulahuen strain (Basombrio \& Besuschio 1982). Moreover, we challenged TCC-immunised mice with a battery of 17 wild $T$. cruzi isolates derived from insect vectors within a $50,000 \mathrm{~km}^{2}$ area of Northern Argentina. The TCC immunisation conferred a significant degree of protection against wild parasites in all cases, as tested by blood mount, xenodiagnosis and histopathological studies (Basombrío et al. 1986).

Is the acquired immunity demonstrated in immunised laboratory mice also operative against natural reservoirs of $T$. cruzi, such as dogs and guinea pigs infected with wild $T$. cruzi by insect vectors?

Most testing of experimental T. cruzi vaccines has been performed under laboratory conditions, which may differ significantly from a field setting. Bloodborne trypomastigotes of a laboratory $T$. cruzi strain are typically injected intraperitoneally or subcutaneously into mice after a short, uniform vaccination-challenge interval. In contrast, a field test of the same vaccine requires vectorial inoculation of insect-borne, wild forms of the parasite at mucosal or intradermal sites in mammals known as natural T. cruzi reservoirs. This protocol also includes relatively long and highly variable vaccination-challenge intervals.
One approach to testing immunity against "natural" infection modalities is oral delivery of vector-borne trypomastigotes in mice, allowing exploration of the particular effectors of mucosal immunity. For example, vaccines composed of recombinant trans-sialidase and the adjuvant oligodeoxynucleotide CPG-ODN were found to be effective, even when administered intranasally, against secondary oral challenge with $T$. cruzi (Hoft et al. 2007).

Guinea pigs, which are both domestic reservoirs of T. cruzi and a convenient experimental model, gave us the opportunity to perform vaccination studies in isolated field yards colonised by Triatoma infestans vectors. TCC parasite cultures used in a live-attenuated vaccine were shown to be unable to propagate outside culture or to feed the natural transmission cycle. After five replications of the experiment, the rate of natural infection, as tested by xenodiagnosis, had been reduced to $39 \%$ in animals preinoculated with $10^{7}$ TCC culture forms, as compared with $63 \%$ in control guinea pigs $(\mathrm{p}<0.02)$ (Fig. 2). After publication of these results (Basombrío et al. 1987), 10 additional experimental series involving a total of 149 control and 157 vaccinated guinea pigs demonstrated a significant degree of protection in the latter group, with infection rates reaching $57.7 \%$ and $36.3 \%$, respectively $(\mathrm{p}<0.001)$.

Following pioneering work conducted in Brazil (Menezes 1969), we attempted experimental vaccination in dogs. Like guinea pigs, dogs are important domestic reservoirs of T. cruzi, displaying high rates of natural infection in some subtropical areas of the Santiago del Estero province of Argentina. In this region, a house-to-house survey allowed the selection of 219 uninfected animals, which were randomised either to be vaccinated with two inoculations of TCC live-attenuated cultures or to remain untreated (Basombrío et al. 1993). After one year of natural exposure to vectors, T. cruzi infection was examined by means of xenodiagnosis and serological hemmaglutination reactions in 148 dogs. It was found that the natural $T$. cruzi infection rate, determined using

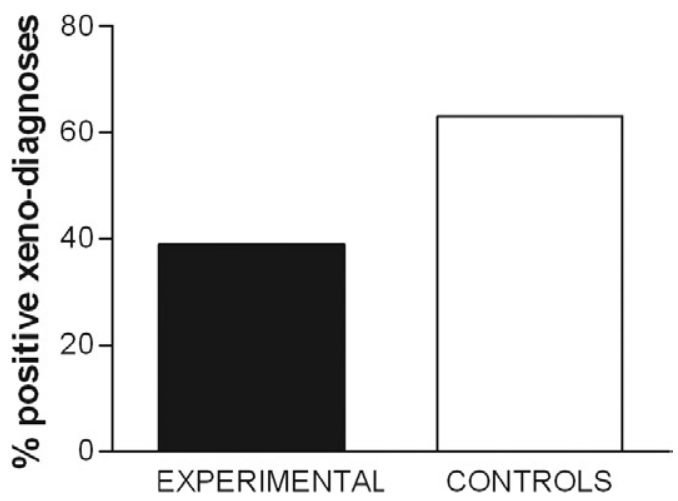

Fig. 2: positivity rate of xenodiagnosis in guinea pigs preinoculated with culture forms of the attenuated Trypanosoma cruzi culture strain (experimental) and non-immunized (controls) after uniform exposure to vectorial $T$. cruzi transmission in experimental corrals (data from Basombrío et al. 1987). 
the control group $(20 / 75 ; 26.7 \%)$ had been reduced $(9 / 73$; $12.3 \%)$ in the vaccinated animals $(\mathrm{p}<0.015)$ (Fig. 3). This trial indicated that natural T. cruzi infection of dogs is an epidemiological condition that may be improved by vaccination, which may help to reduce the risk of spreading infection to humans.

Can measurements of parasite trafficking in the transmission cycle inform assessment of protective immunity?

Several successful vaccines exert a "herd effect" in addition to protecting the individual, whereby transmission of the target pathogen from vaccinated to non-vaccinated hosts is partially blocked. Theoretically, this effect may be measured for the complex host-vector transmission cycle of $T$. cruzi in two ways. Host-to-vector traffic can be correlated to the host's ability to transfer the parasite to uninfected insect vectors. This measurement may be obtained by using xenodiagnosis to quantify the proportion of insects infected after a standardised blood meal from a single host. Meanwhile, vector-to-host traffic can be correlated to the ability of insect vectors to transmit the infection to new hosts. This measurement can be obtained by determining the number of bites necessary for infection (NBNI), a calculation applicable to T. cruzi transmission in standardised guinea pig yards (Basombrío et al. 1996).

Host-to-vector traffic was measured during several experiments in which guinea pigs living in T. infestanscolonised yards were vaccinated with live-attenuated $T$. cruzi. Totals of 2,040 and 1,960 insects were allowed to feed on control and vaccinated guinea pigs, respectively, and were then studied for infection in pools of 10 . The positivity rate in xenodiagnosis was $38 \%$ for controls and only $18 \%$ for vaccinated animals $(\mathrm{p}<0.001)(\mathrm{Ba}-$ sombrío et al. 1987).

A similar measurement was performed in vaccinated dogs. Here, the insects were not analysed in pools but individually and xenodiagnoses of uninfected dogs were excluded from the study. Again, the positivity rate was significantly reduced in the vaccinated group, from $52 \%$ in control animals to $29 \%(\mathrm{p}<0.001)$ (Basombrío et al. 1993). Taken together, the results indicate that in both guinea pigs and dogs subjected to an environment of high vectorial T. cruzi transmission, the force of host-tovector infection was reduced by vaccination. The reduction of T. cruzi transmission from dogs to T. infestans after experimental vaccination has also been confirmed by Basso et al. (2007).

Vector-to-host $T$. cruzi traffic, as measured by NBNI determinations, was estimated in guinea pig yard experiments. Parameters such as days of exposure, average number of insects per guinea pig, proportion of infected vectors, proportion of fed vectors, number of guinea pigs and proportion of hosts infected were controlled. Whereas an average of 4,973 bites was calculated to infect a control guinea pig, an average of 21,307 bites (a 4.28-fold increase) was necessary to produce the same effect in a vaccinated animal (Basombrío et al. 1997). These results suggest that the effects of protective immunisation on domestic mammalian reservoirs of $T$. cruzi may be measured not only in terms of parasite load, disease and mortality, but also in terms of vectorial parasite traffic (Fig. 4).

In conclusion, protective immunity against $T$. cruzi has been well demonstrated in both humans and experimental animal models. However, many escape mechanisms exist whereby parasites may overcome host protective immunity. While T. cruzi implements some of these mechanisms, it is unable to generate diverse antigenic lineages or to switch membrane antigens rapidly, which would preclude vaccination. Recent advances toward the development of genetically modified parasites capable of inducing a protective immune response without causing pathology present a promising new ap-

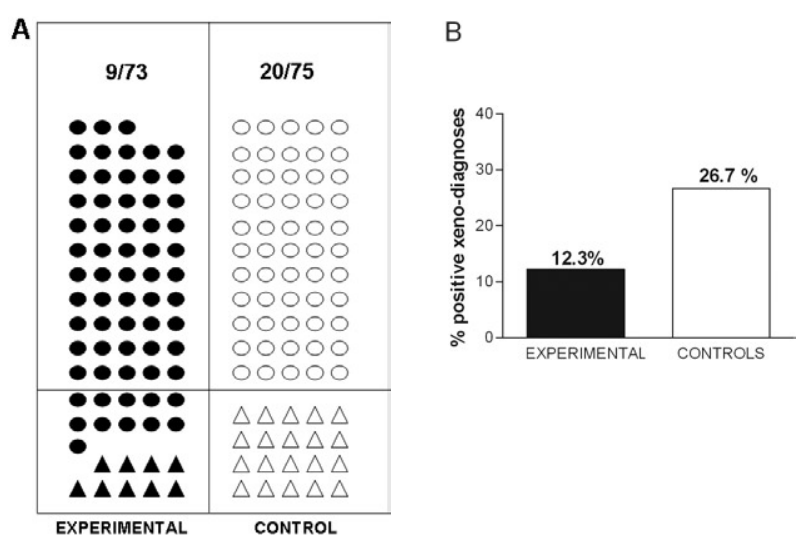

Fig. 3: diagrams representing Trypanosoma cruzi infection of dogs after natural exposure to vectorial transmission in Santiago del Estero, Argentina. The experimental group was preinoculated with culture forms of the attenuated T. cruzi culture (TCC) strain. A: each dot represents one dog (black: preinoculated with TCC; white: non immunized controls); $\triangle$ and $\mathbf{\Delta}$ : infected; $\bigcirc$ and $\mathbf{O}$ : not infected; $\mathrm{B}$ : percentage of infected dogs in each group, as detected by xenodiagnosis (data from Basombrío et al. 1993).

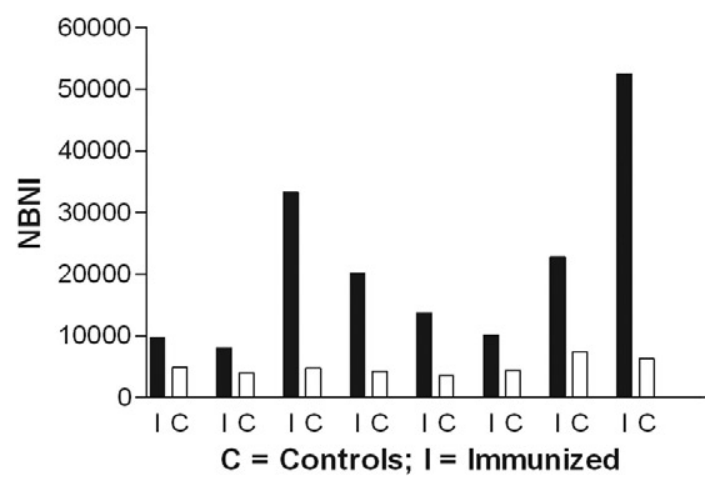

Fig. 4: estimated number of vector bites necessary to infect a guinea pig (NBNI), as measured in animals preinoculated with culture forms of the attenuated TCC Trypanosoma cruzi strain (black bars) and controls (white bars). Animals were exposed to controlled vectorial transmission in experimental corrals. Four separate experiments are represented. Each experiment was evaluated a two different times, generating eight comparable measurements, represented by a black and a white bar (data from Basombrío et al. 1997). 
proach to vaccination against $T$. cruzi (Basombrío et al. 2002a, Barrio et al. 2007, Zago et al. 2008). Beyond reducing immunopathology, such a vaccine would potentially establish robust, long-lasting protection without parasite persistence.

Do we need a human T. cruzi vaccine at present? The success of well-established vector control and alternative prevention methods indicates that a human vaccine is not imperative but that vaccination of domestic reservoirs may be desirable in some cases of Chagas disease. However, epidemiological situations do change over decades, such as the development of insecticide resistance by vectors or the appearance of new transmission modalities. In these situations, the need for additional prevention methods, including vaccination, may arise.

\section{REFERENCES}

Albareda MC, Laucella SA, Alvarez MG, Armenti AH, Bertochi G, Tarleton RL, Postan M 2006. Trypanosoma cruzi modulates the profile of memory $\mathrm{CD} 8^{+} \mathrm{T}$ cells in chronic Chagas' disease patients. Int Immunol 18: 465-471.

Alvarez MG, Postan M, Weatherly DB, Albareda MC, Sidney J, Sette A, Olivera C, Armenti AH, Tarleton RL, Laucella SA 2008. HLA Class I-T cell epitopes from trans-sialidase proteins reveal functionally distinct subsets of CD8 T cells in chronic Chagas disease. PLoS Negl Trop Dis 2: e288.

Appay V, Dunbar PR, Callan M, Klenerman P, Gillespie GM, Papagno L, Ogg GS, King A, Lechner F, Spina CA, Little S, Havlir DV, Richman DD, Gruener N, Pape G, Waters A, Easterbrook P, Salio M, Cerundolo V, McMichael AJ, Rowland-Jones SL 2002. Memory $\mathrm{CD}^{+} \mathrm{T}$ cells vary in differentiation phenotype in different persistent virus infections. Nat Med 8: 379-385.

Appay V, Rowland-Jones SL 2004. Lessons from the study of T-cell differentiation in persistent human virus infection. Semin Immunol 16: 205-212.

Barber DL, Wherry EJ, Masopust D, Zhu B, Allison JP, Sharpe AH, Freeman GJ, Ahmed R 2006. Restoring function in exhausted CD8 T cells during chronic viral infection. Nature 439: 682-687.

Barrio AB, Van Voorhis W, Basombrío MA 2007. Trypanosoma cruzi: attenuation of virulence and protective immunogenicity after monoallelic disruption of the $c u b$ gene. Exp Parasitol 117: 382-389.

Basombrío MA 1981. Resistencia a reinfecciones por el Trypanosoma cruzi en ratones chagásicos. Medicina (Bs. As.) 41: 230-232.

Basombrío MA 1990. Trypanosoma cruzi: partial prevention of the natural infection of guinea pigs with a killed parasite vaccine. Exp Parasitol 71: 1-8.

Basombrío MA, Arredes H 1987. Long-term immunological response induced by attenuated Trypanosoma cruzi in mice. J Parasitol 73: 236-238.

Basombrío MA, Arredes H, Rossi R, Molina de Raspi E 1986. Histopathological and parasitological evidence of immunization of mice against challenge with 17 wild isolates of Trypanosoma cruzi. Int J Parasitol 16: 375-380.

Basombrío MA, Arredes H, Uncos R, Alvarez E 1987. Field trial of vaccination against American trypanosomiasis (Chagas' disease) in domestic guinea pigs. Am J Trop Med Hyg 37: 57-62.

Basombrío MA, Besuschio S 1982. Trypanosoma cruzi culture used as vaccine to prevent chronic Chagas' disease in mice. Infect Immun 36: 351-356.
Basombrío MA, Besuschio S, Cossio P 1982. Side effects of immunization with live attenuated Trypanosoma cruzi in mice and rabbits. Infect Immun 36: 342-350.

Basombrío MA, Gómez L, Padilla AM, Ciaccio M, Nozaki T, Cross GAM 2002a. Targeted deletion of the $g p 72$ gene decreases the infectivity of Trypanosoma cruzi for mice and insect vectors. J Parasitol 88: 489-493.

Basombrío MA, Gorla D, Catalá S, Segura MA, Mora MC, Gomez L, Nasser J 1996. Number of vector bites determining the infection of guinea pigs with Trypanosoma cruzi. Mem Inst Oswaldo Cruz 91: 421-423.

Basombrío MA, Nasser J, Segura MA, Gomez L 1997. Trypanosoma cruzi: effect of immunization on the risk if vector-delivered infection in guinea pigs. J Parasitol 83: 1059-1062.

Basombrío MA, Segura MA, Mora MC, Gómez L 1993. Field trial of vaccination against american trypanosomiasis (Chagas' disease) in dogs. Am J Trop Med Hyg 49: 143-151.

Basombrío MA, Segura MA, Nasser J 2002b. Relationship between long-term resistance to Trypanosoma cruzi and latent infection, examined by antibody production and polymerase-chain reaction in mice. J Parasitol 88: 1107-1112.

Basso B, Castro I, Introini V, Truyens C, Moretti E 2007. Vaccination with Trypanosoma rangeli reduces the infectiousness of dogs experimentally infected with Trypanosoma cruzi. Vaccine 25: 3855-3858.

Bustamante JM, Bixby LM, Tarleton RL 2008. Drug-induced cure drives conversion to a stable and protective CD8+ T central memory response in chronic Chagas' disease. Nat Med 14: 542-550.

Cardozo R 2003. Estudio del cuadro histopatológico provocado por aislados de diversos linajes de Trypanosoma cruzi provenientes de la Provincia del Chaco, Thesis, Universidad Nacional de Salta, Argentina, p. 33-34.

Cuneo C, Molina de Raspi E, Basombrío MA 1989. Prevention of electrocardiographic and histopathologic alterations in the murine model of Chagas disease by preinoculation of an attenuated Trypanosoma cruzi strain. Rev Inst Med Trop São Paulo 31: 248-255.

Garg N, Tarleton RL 2002. Genetic immunization elicits antigen-specific protective immune responses and decreases disease severity in Trypanosoma cruzi. Infect Immun 70: 5547-5555.

Gomez LE, Nasser JR, Basombrío MA 1996. Complete immunization against Trypanosoma cruzi verified in individual mice by complement-mediated lysis. Mem Inst Oswaldo Cruz 91: 56-61.

Hinrichs CS, Gattinoni L, Restifo NP 2006. Programming CD8 ${ }^{+}$ $\mathrm{T}$ cells for effective immunotherapy. Curr Opin Immunol 18: 363-370.

Hoft DF, Eickhoff CS, Giddings OK, Vasconcelos JRC, Rodrigues MM 2007. Trans-sialidase recombinant protein mixed with CpG motif-containing oligodeoxynucleotide induces protective mucosal and systemic Trypanosoma cruzi immunity involving CD8 $8^{+}$CTL and B cell-mediated cross-priming. J Immunol 179: 6889-6900.

Karp CL, Arwaerter PG 2007. Coinfection with HIV and tropical infectious diseases. I. Protozoal pathogens. Clin Infect Dis 45: 1208-1213.

Krettli A, Brener Z 1982. Protective effects of specific antibodies in Trypanosoma cruzi infections. J Immunol 128: 2008-2012.

Laucella SA, Postan M, Martin D, Hubby Fralish B, Albareda MC, Alvarez MG, Lococo B, Barbieri G, Viotti RJ, Tarleton RL 2004. Frequency of interferon-gamma-producing $\mathrm{T}$ cells specific for 
Trypanosoma cruzi inversely correlates with disease severity in chronic human Chagas disease. J Infect Dis 189: 909-918.

Machado AV, Cardoso JE, Claser C, Rodrigues MM, Gazzinelli R, Bruna-Romero O 2006. Long-term protective immunity induced against Trypanosoma cruzi infection after vaccination with recombinant adenoviruses encoding amastigote surface protein-2 and trans-sialidase. Human Gene Therapy 17: 898-908.

Martin DL, Tarleton RL 2005. Antigen-specific T cells maintain an effector memory phenotype during persistent Trypanosoma cruzi infection. J Immunol 174: 1594-1601.

Martin DL, Tarleton R 2006. CD8 ${ }^{+}$T-cell responses to Trypanosoma cruzi are highly focused on strain-variant trans-sialidase epitopes. PLoS Pathog 2: e77.

Menezes H 1969. Active immunization of dogs with a non virulent strain of Trypanosoma cruzi. Rev Inst Med Trop São Paulo 11: 258-263.

Muñoz-Fernandez MA, Fernandez MA, Fresno M 1992. Activation of human macrophages for the killing of intracellular Trypanosoma cruzi by TNF- $\alpha$ and IFN- $\gamma$ through a nitric oxide-dependent mechanism. Immunol Lett 33: 35-40.

Simao Ferreira M 1999. Chagas disease and immunosuppression. Mem Inst Oswaldo Cruz 94: 325-327.

Tarleton RL 2001. Parasite persistence in the aetiology of Chagas disease. Int J Parasitol 31: 550-554.

Tarleton RL 2003. Chagas disease: a role for autoimmunity? Trends Parasitol 19: 447-451.
Tarleton RL, Grusby MJ, Postan M, Glimcher HL 1996. Trypanosoma cruzi infection in MHC-deficient mice: further evidence for the role of both class I- and class II-restricted T cells in immune resistance and disease. Int Immunol 8: 13-22.

Tarleton RL, Koller BH, Latour A, Postan M 1992. Susceptibility of [beta] 2-microglobulin-deficient mice to Trypanosoma cruzi infection. Nature 356: 338-340.

Tzelepis F, Alencar BCG, Penido MLO, Gazzinelli RT, Persechini PM, Rodrigues MM 2006. Distinct kinetics of effector CD8 $8^{+}$cytotoxic T cells after infection with Trypanosoma cruzi in nave or vaccinated mice. Infect Immun 74: 2477-2481.

Vasconcelos JR, Hiyane MI, Marinho CR, Claser C, Machado AM, Gazzinelli RT, Bruña-Romero O, Alvarez JM, Boscardin SB, Rodrigues MM 2004. Protective immunity against Trypanosoma cruzi infection in a highly susceptible mouse strain after vaccination with genes encoding the amastigote surface protein-2 and trans-sialidase. Hum Gene Ther 15: 878-886.

Vogt J, Alba Soto CD, Mincz MP, Mirkin GA 2008. Impaired Trypanosoma cruzi-specific IFN-gamma secretion by T cells bearing the BV9 T-cell receptor is associated with local IL-10 production in non-lymphoid tissues of chronically infected mice. Microbes Infect 10: 781-790.

Zago MP, Barrio AB, Cardozo RM, Duffy T, Schijman AG, Basombrío MA 2008. Impairment of infectivity and immunoprotective effect of a LYT1 null mutant of Trypanosoma cruzi. Inf Immun 76: 443-451. 